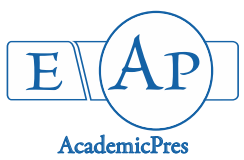

Coca Morante M and Tapia Ponce N (2021)

Notulae Scientia Biologicae

Volume 13, Issue 3, Article number 10986

DOI: $10.15835 / \mathrm{nsb} 13310986$

Research Article

\title{
Viral diseases associated to wild potatoes (Solanum L. section Petota Dumort) and its conservation in Bolivia
}

\author{
Mario COCA MORANTE ${ }^{1 *}$, Nelson TAPIA PONCE ${ }^{2}$ \\ ${ }^{1}$ Universidad Mayor de San Simón, Facultad de Ciencias Agrícolas y Pecuarias, Departamento de Fitotecnia, Laboratorio de \\ Fitopalogia, Av. Petrolera km 5, Cochabamba,Bolivia; m.cocamorante@umss.edu.bo ( ${ }^{*}$ corresponding author) \\ ${ }^{2}$ Universidad Mayor de San Simón, Agroecología Universidad Cochabamba (AGRUCO), Facultad de Ciencias Agrícolas y Pecuarias, \\ Av.Petrolera km 5, Cochabamba, Bolivia;n.tapia@umss.edu.bo
}

\begin{abstract}
Different species of wild potatoes are distributed in highlands and inter-Andean valleys of Bolivia. In recent years, potato virus's incidence has been reported in native and modern varieties of Andean areas of Peru, Ecuador and Bolivia, which could also affect wild potatoes. The main of the present investigation was to identify potato viruses using DAS ELISA in wild potatoes species, from isolated collection places and intensive potato cultivation places in the Bolivian Andean region. Folioles samples from different wild potato species were collected considering isolated distribution areas and potato cultivation intensity areas. The samples were analysed using DAS ELISA for PRX, PVY, PLRV, APLV and APMoV viruses. The results show that in the high Andean zones and inter-Andean valleys some species are contaminated with PVX, PVY and PLRV viruses and not with APLV and APMoV. In the high Andean areas with intensive potato cultivation $S$. acaule is contaminated with PVX and S. megistacrolobum with PVY and PLRV; however, in the inter-Andean valley areas with intensive potato cultivation, S. brevicaule is contaminated with PVY and S. berthaultii with PVY and PLRV. In isolated or remote areas $S$. capsicibaccatum, $S$. microdontum and Solanum spp. they are not contaminated with any analysed viruses.
\end{abstract}

Keywords: disease intensity; gene losses; in situ conservation; plant viruses; wild genotypes

\section{Introduction}

There are about 100 wild potato species distributed from the southwestern United States to Chile, with two centers of diversity, in central Mexico and in the central Andes (Cai et al., 2011). In the Bolivian Andean region, wild potatoes are distributed in high Andean areas $(>3000 \mathrm{~m})$ and inter-Andean valleys $(<3000 \mathrm{~m})$, for example, Solanum acaule and Solanum achacachense on highland areas and Solanum tarijense and Solanum berthaultii on temperate areas (Hawkes and Hjerting, 1989; Ochoa, 1990). Crop improvement, particularly under climate change, depends on the genetic diversity of our plant genetic resources, which are arguably inadequately conserved and poorly used. Plant genetic resources are the "total genetic diversity of cultivated species and their wild relatives, much of which may be valuable to breeders" (Ford-Lloyd et al., 2011). Crop wild relatives have been extremely valuable in adapting crop varieties to changing disease pressures, farming practices, market demands, and climatic conditions (Dempewolf et al., 2017). According to Cai et al. (2011),

Received: 05 Jun 2021. Received in revised form: 01 Aug 2021. Accepted: 09 Aug 2021. Published online: 18 Aug 2021.

From Volume 13, Issue 1, 2021, Notulae Scientia Biologicae journal uses article numbers in place of the traditional method of continuous pagination through the volume. The journal will continue to appear quarterly, as before, with four annual numbers. 
extreme resistance (ER) has been identified in the wild potato species $S$. chacoense, $S$. hougasii and $S$. stoloniferum, while Hypersensitive resistance $(\mathrm{HR})$ to Potato virus $\mathrm{Y}(\mathrm{PVY})$ ordinary $(\mathrm{O})$ strain group $\left(\mathrm{PVY}^{\mathrm{O}}\right)$ has been reported in $S$. chacoense, $S$. demissum, $S$. megistacrolobum, S. polyadenium, S. sparsipilum and $S$. stoloniferum.

However, some factors such as the cultivation intensity of modern varieties and climatic change to the Bolivian high Andean region could be causing some increase of virus diseases with collateral effects on wild potatoes contamination and that could affect it in the long-term conservation. Since the 1980s, surveys have been conducted using ELISA to detect the most common potato viruses (PVY, PVX, PVS, PLRV, APMoV, APLV) in potatoes growing at higher altitude $(>3000 \mathrm{~m})$ in the Peruvian highlands (Kreuze et al., 2020). In recent years, Potato virus X (PVX), PVY, Potato leaf roll virus (PLRV) and Andean potato leaf virus (APLV) have been reported in both agro-ecological zones and the potato native crops are being affected by virus diseases (Coca-Morante et al., 2020, unpublished data). The main of the present investigation was to identify potato viruses using DAS ELISA in wild potatoes species, from isolated collection places and from intensive potato cultivation places in the Bolivian Andean region.

\section{Materials and Methods}

\section{Study area and collection}

In 2017 and 2018, wild potato sample species were collected from different Andean agro-ecological zones of Bolivia (Figures 1-2). They were collected from three geographically distant points observing the Ochoa (1990) and Hawkes and Hjerting (1989) references for some species and according to our own experience references (Table 1). On the one hand, according to Ochoa (1990) and Hawkes and Hjertin references (1989), in the center of Bolivia, both the valley central and the high Andean areas of Cochabamba department, to our own references, in Pacuni locality, Sorata municipality from Larecaja Province of La Paz department, and finally, in southern Bolivia, near Tupiza city, Tupiza municipality from Province Sud Chichas of Potosí department (Figure 1) (Table 1). Taxonomy group, ploidy of each specie collected and the Agro ecological characteristics of each collection place is summarized in the Table 2.

\section{Leaf samples and DAS ELISA virus analysis}

From each selected area, leaflet samples of specimens were collected for serological analysis with DAS ELISA test. The sample collection points were random where plant populations of each species were detected. And at each point, 3 leaflets were collected per plant and between 3 to 5 plants per point. In each point were collected leaflets showing no symptoms (apparently healthy plants), mild and moderate viral symptoms ( $\mathrm{n}=3$ leaflet of each type (plant) per plot and 3 to 5 plots per point collection, that means 9 to 15 leaflets per specie per locality. Total $n=91-115$ leaflets in Aymara region per year were taken from the mid-plant area during flowering (January to February). Samples were placed in BIOREBA Universal $12 \times 15 \mathrm{~cm}$ extraction bags, following the manufacturer's protocol, to avoid contamination. These bags were then placed in Tecnopor box containing ice and taken to the laboratory. The presence of PVY, PLRV, PVX, APLV and APMoV in leaf samples was sought using Double-Antibody Sandwich-ELISA kits from BIOREBA (these kits employ polyclonal antibodies for antigen capture and visualization [conjugated with alkaline phosphatase]), according to the manufacturer's instructions. Colorimetry was performed using a Multiscan device from Labsystem. Frequency histograms were produced in order to define cut-offs and thus allow the detection of false negatives and positives. Cut-offs were determined using the formula mean $+3 s \times 1$.1, where 'mean' refers to the mean values of negative control and 's' to its standard deviation, as recommended by the kit manufacturer. The incidence (percentage) of viral infection was determined as the number of positive samples/total number of samples $\times 100$. 


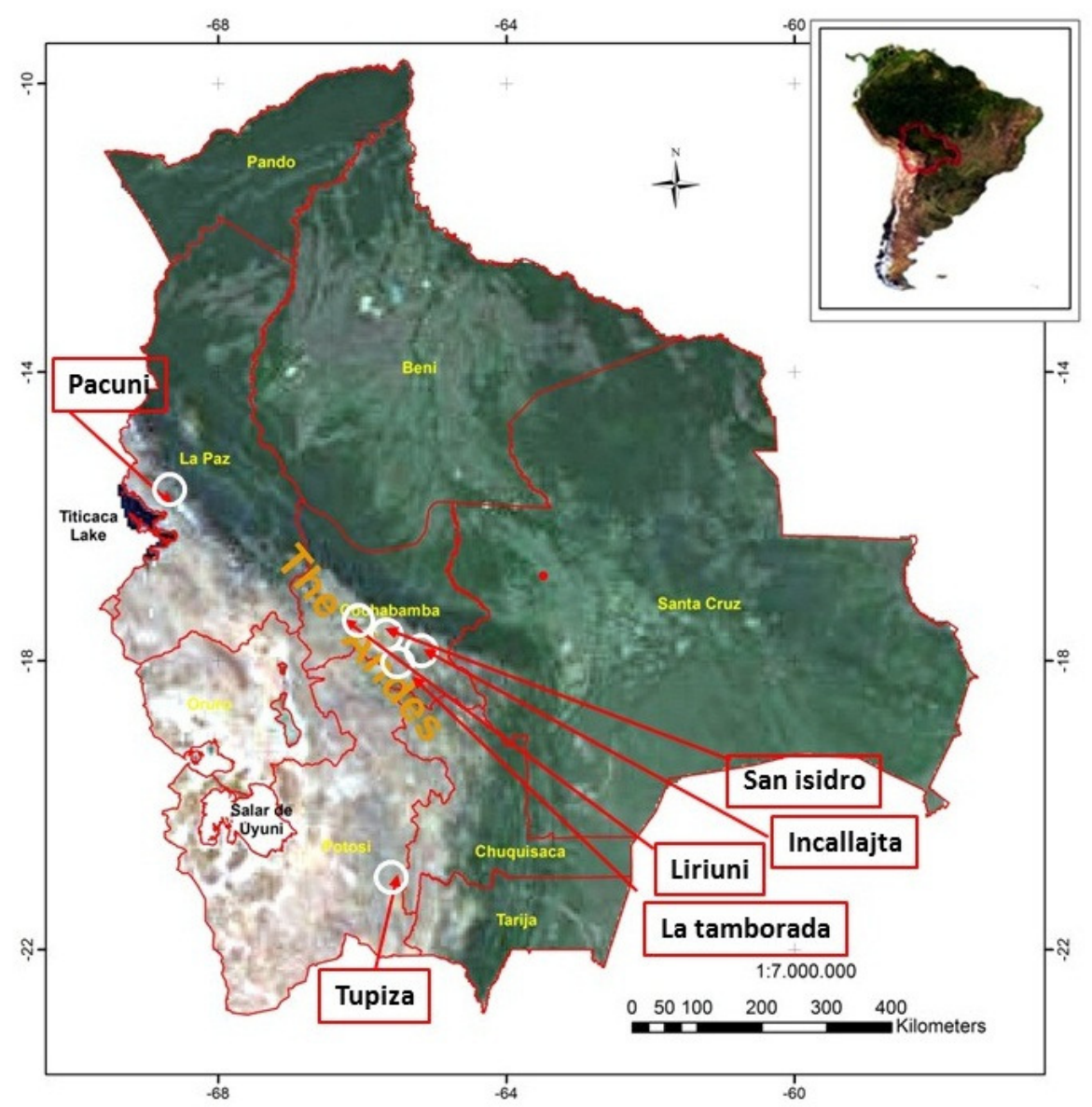

Figure 1. Map localization of the collection samples points of potato wild relatives in the Andean region of Bolivia for virus analysis Elaboration: CISTEL - FCAyP - UMSS

Table 1. Potato wild species samples collection from different parts of the Andean region of Bolivia for viruses' identification by DAS ELISA

\begin{tabular}{|l|c|c|c|c|c|}
\hline \multicolumn{1}{|c|}{ Locality } & Province & Department & Specie & Meters & Type locality / Author \\
\hline Calientes & Ayopaya & Cochabamba & Solanum acaule & 4155 & New collection area $\left(^{*}\right)$ \\
\hline Tamborada & Cercado & Cochabamba & Solanum brevicaule & 2570 & New collection area $\left(^{*}\right)$ \\
\hline Tupiza & Sud Chichas & Potosi & Solanum brevicaule & 2950 & New collection area $\left(^{*}\right)$ \\
\hline Tamborada & Cercado & Cochabamba & Solanum berthaultii & 2570 & New collection area $\left(^{*}\right)$ \\
\hline Incallajta & Pocona & Cochabamba & Solanum microdontum & 2650 & $\begin{array}{c}\text { Incallajta, Hawkes and Hjerting } \\
(1989)\end{array}$ \\
\hline Liriuni & Quillacollo & Cochabamba & $\begin{array}{c}\text { Solanum } \\
\text { capsicibaccatum }\end{array}$ & 2450 & Liriuni, Ochoa $(1990)$ \\
\hline San Isidro & Sacaba & Cochabamba & Solanum toralapanum & 3245 & New collection area $\left(^{*}\right)$ \\
\hline P'alta loma & Colomi & Cochabamba & $\begin{array}{c}\text { Solanum } \\
\text { megistacrolobum }\end{array}$ & 3820 & New collection area $\left(^{*}\right)$ \\
\hline Pacuni & Larecaja & La Paz & Solanum spp & 4150 & New collection area $\left(^{*}\right)$ \\
\hline
\end{tabular}

$\left({ }^{*}\right)=$ Unpublished data; Years: 2017 to 2018 

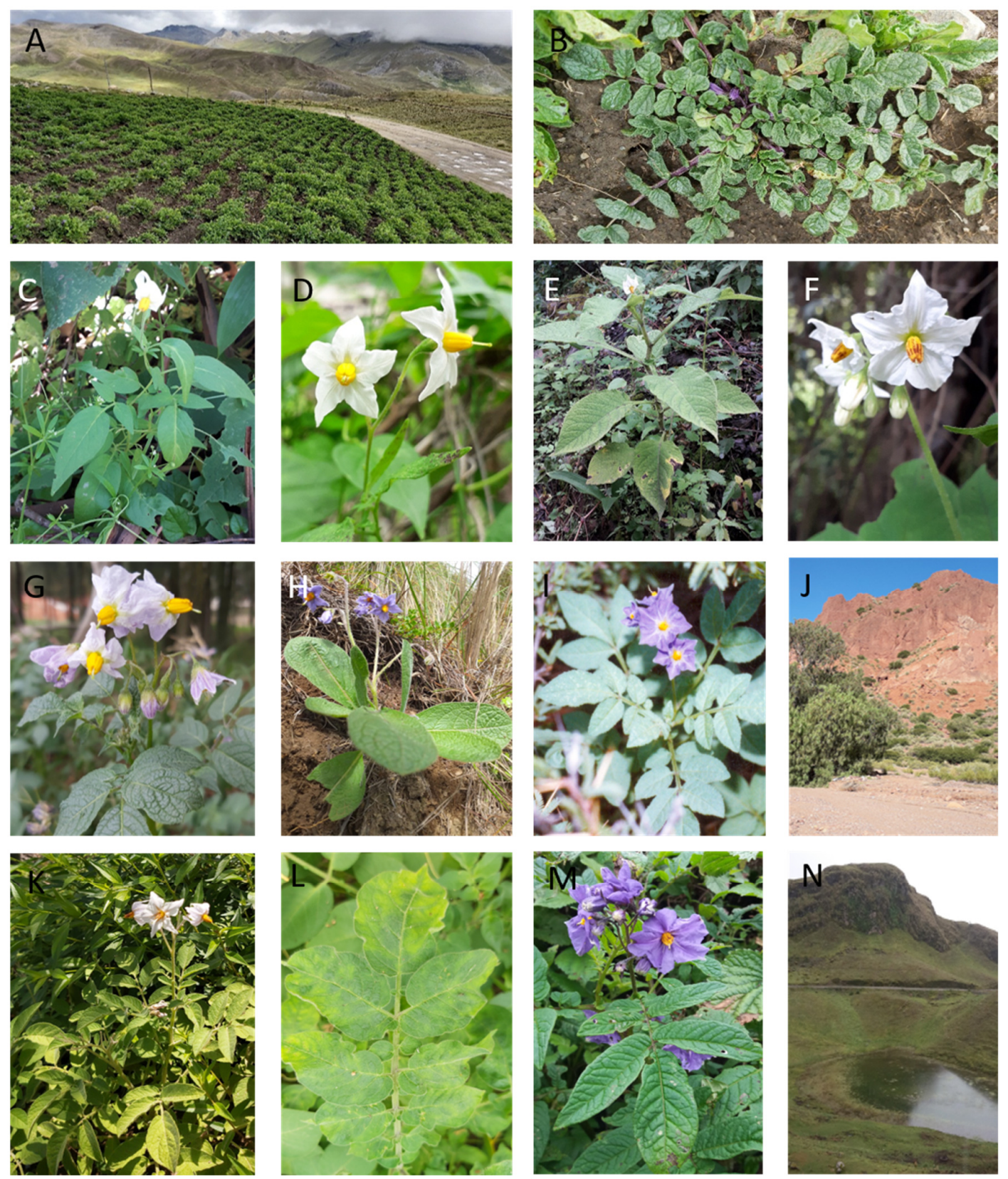

Figure 2. A: Smallholder plot whit potato luk'y variety (S. x juzeckzukii), Calientes locality; B: S. acaule, Calientes Locality; C: S. capsicibaccatum, Liriuni, Type locality; D: S. capsicibaccatum, stellate form; E: $S$. microdontum, Incallajta type locality; F: S. microdontum semi stellate form; G: S. brevicaule, Tamborada; H: S. toralapanum, San Isidro; I: S. brevicaule, Tupiza, Potosí; J: S. brevicaule, type locality, Tupiza, Potosí; K: S. berthaultii, type locality; L: Severe mosaic S. ber, M: Solanum spp, Pacuni, La Paz; N: Solanum spp., Type locality. 
Table 2. Taxonomy group, ploidy of each specie collected and the Agro ecological characteristics of each collection place. Years: 2017 to 2018

\begin{tabular}{|l|c|c|c|}
\hline \multicolumn{1}{|c|}{ Specie } & Serie & Ploidy & Characteristics of sample collection place \\
\hline Solanum acaule & Acaulia & $4 x$ & Cool and isolated high Andean area \\
\hline Solanum brevicaule & Tuberosa & $2 x$ & Inter-Andean temperate valley of intensive agriculture \\
\hline Solanum brevicaule & Tuberosa & $2 x$ & Temperate inter-Andean and isolated area \\
\hline Solanum berthaultii & Commersoniana & $2 x$ & Inter-Andean temperate valley of intensive agriculture \\
\hline Solanum microdontum & Tuberosa & $2 x$ & Temperate inter-Andean and isolated area \\
\hline Solanum capsicibaccatum & Circaeifolia & $2 x$ & Temperate inter-Andean and isolated area \\
\hline Solanum toralapanum & Megistacrolobai & $2 x$ & Cool and isolated high Andean area \\
\hline Solanum megistacrolobum & Megistacrolobai & $2 x$ & Cool and isolated high Andean area \\
\hline Solanum spp & Tuberosa & $?$ & Cool and isolated high Andean area \\
\hline
\end{tabular}

\section{Results}

In 2017, wild potatoes from P'alta loma and La tamborada (Cochabamba) localities were infected with PVY-Poly and PLRV viruses, while in Pacuni (La Paz) locality they did not register any virus (Figure 3A). Therefore, there is no average virus incidence by species in Pacuni locality (Figure 2M, N), on the other hand, in Solanum megistacrolobum of P'alta loma locality, the incidence of PVY-Poly was 16\% and PLVR of 18\% and in Solanum brevicaule (Figure 2G) and Solanum berthaultii (Figure 2K, L) from the "La tamborada" locality, the incidence of PVY-Poly was 33\% and PVY-Poly of 14\% and PLVR was 57\%, respectively (Figure 2, 3B).
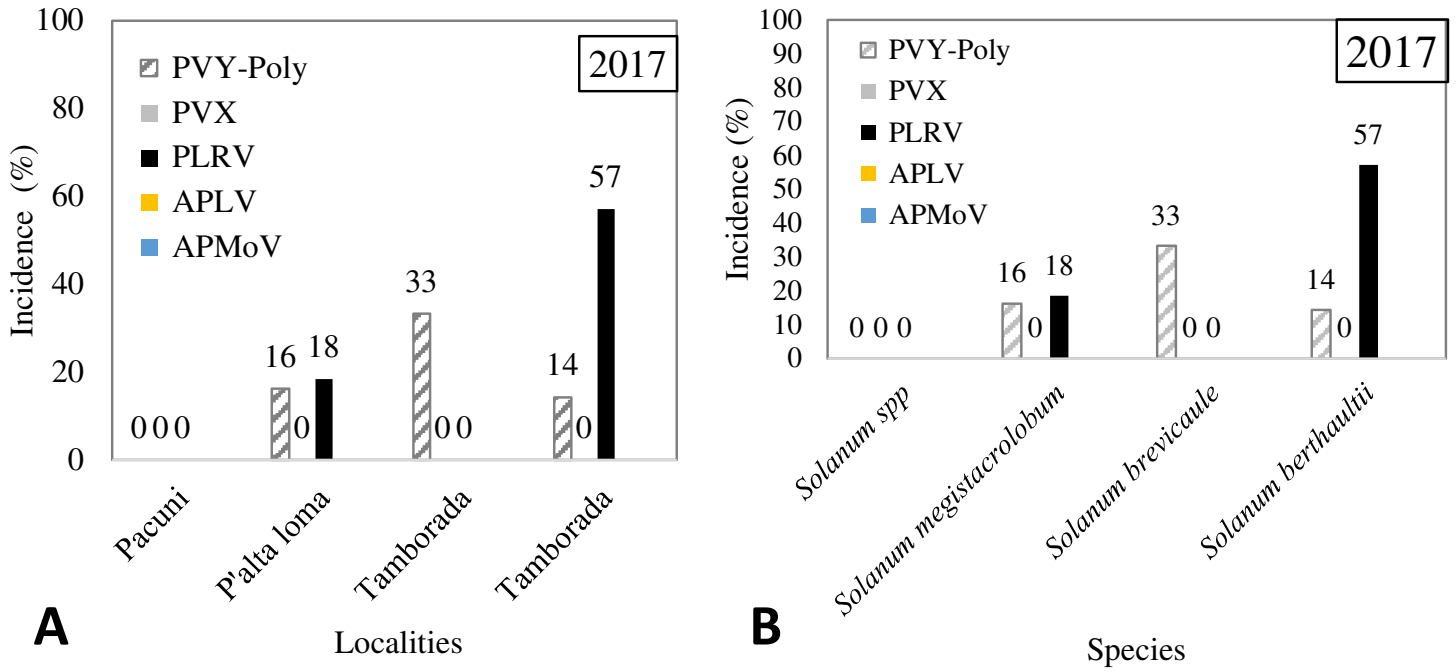

Figure 3. Viruses' incidence on potato wild relatives in the Andean region of Bolivia. A: 2017, virus incidence by locality; B: 2017, virus incidence by specie

In 2018, the wild species of the Calientes and La tamborada localities, had been infected; however, Incallajta, Liriuni, San Isidro and Tupiza localities did not register viral infections (Figure 4C). The virus incidence in Solanum acaule (Figure 2B) from the "Calientes" locality had PVX infection (50\%) (Figure 4D), S. brevicaule (Figure 2M) from "La tamborada" locality showed infection with PVY-Poly (20\%) and PVY-N (20\%), S. berthaultii (Figure 2k, L) with PVY-Poly (25\%) and PVY-N (25\%) and Solanum microdontum 
(Incallajta) (Figure 2E, F), Solanum capsicibaccatum (Liriuni) (Figure 2C), Solanum toralapanum(San Isidro) (Figure 2H) and Solanum brevicaule (Tupiza) (Figure 2I, J) did not present virus infection.
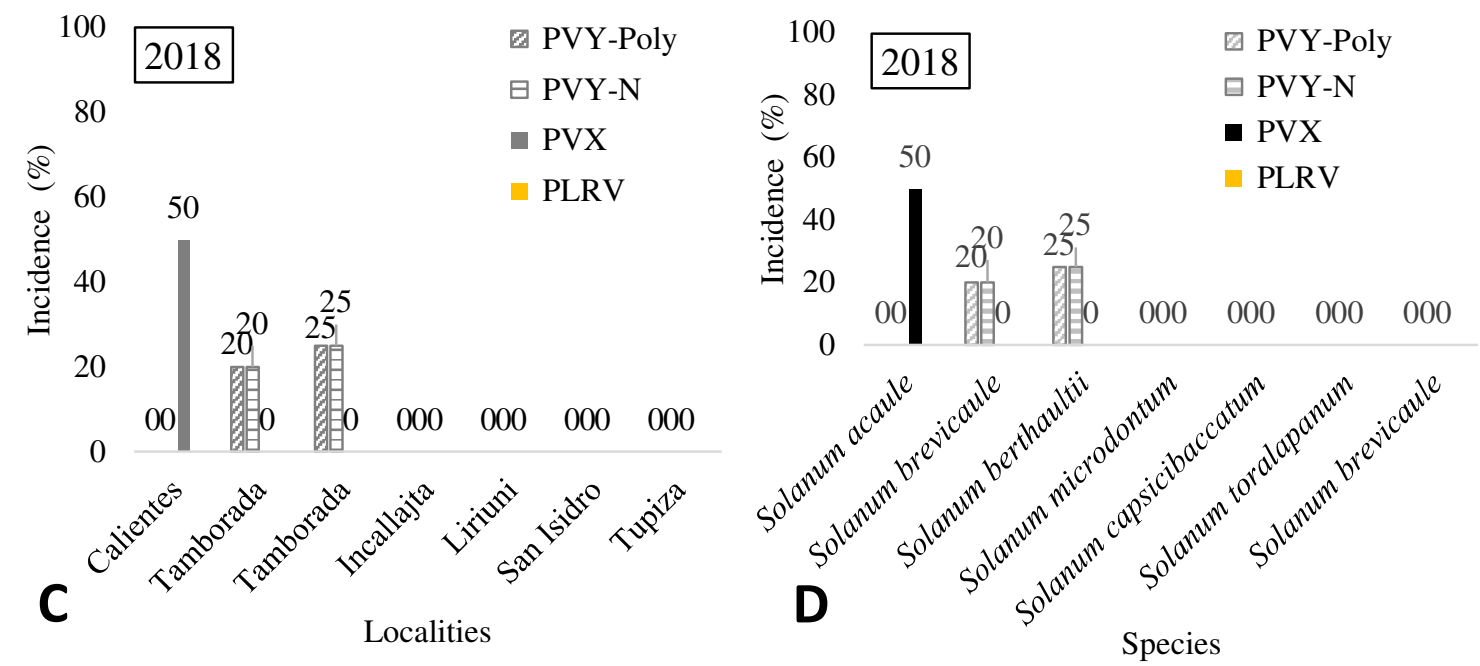

Figure 4. Viruses' incidence on potato wild relatives in the Andean region of Bolivia C: 2018, virus incidence by locality; D: 2018, virus incidence by specie.

\section{Discussion}

The results of the present study show that wild potatoes from some sectors of the Bolivian Andean region (high Andean zones $>3,000 \mathrm{~m}$ and inter-Andean valleys, $<3,000 \mathrm{~m}$ ), are infected with viral potato diseases and others are not. The identified viruses were: PVX, PVY-Poly, PVY-N and PLRV, and APLV and $\mathrm{APMoV}$ were not registered. These identified viruses were previously reported for Andean countries, but affecting cultivated potatoes. According to Fribourg (1980), the most economically important potato viruses are PLRV and PVY, but in the highlands of the Andes, also PVX, APMV and APLV. On another hand, $S$. acaule contains resistance genes to PVX. According Bertschinger et al. (1990) in the Peruvian central and southern highlands, the incidence of viruses was studied in fields and tuber seeds of native and modern cultivars, and report that PVX was the most incident virus (37-82\%), PVS (19-53\%); PLRV and PVY were of 0.7-6.8\%. It's important to note that PLRV was widely spread in native cultivars (24\%). On another hand, Garcia and Gandarillas (1992), indicate that in highland area of Carrasco Province, Cochabamba department, farmers' fields planted with Huaych'a, a potato native variety, the most frequently viruses found were: PVX, APLV, APMoV and PVY, being found PVS and PLRV to a lesser extent. Later, Kreuz et al. (2020), say that since the 1980s, surveys have been conducted using ELISA to detect the most common potato viruses (PVY, PVX, PVS, PLRV, APMoV, APLV) in potatoes growing areas at higher altitude $(>3000 \mathrm{~m})$ in the Peruvian highlands and similar viruses and incidences were found in higher altitude plantings in Ecuador. Furthermore, these authors report that when similar surveys were undertaken at lower altitudes in the Andean region $(<3000 \mathrm{~m})$, the findings resembled those in other areas of the world, with PVY and PLRV dominating.

Our results are similar to the reported by Fribourg (1980), Bertschinger et al. (1990), Garcia and Gandarillas (1992) and Kreuz et al. (2020) in relation to the PVX, PVY and PLRV importance in high Andean areas with the difference that these viruses are affecting wild potatoes as $S$. acaule (PVX), S. megistacrolobum (PVY and PLRV) S. brevicaule (PVY) and S. berthaultii (PVY and PLRV). These two viruses (PVY and PLRV) are consistently affecting (two years) S. brevicaule and S. berthaultii. According Fribourg (1980) and Barker and Dale (2006), S. acaule has resistance genes to PVX but not to PVX $\mathrm{HB}_{\text {B }}$ and Hypersensitive Response (HR) and Extreme Resistance (ER), respectively. According Cai et al. (2011), S. megistacrolobum has HR to PVYO 
(common strain), but in our study we found that $S$. megistacrolobum is affected by PVY. According Barker and Dale (2006), two principal groups of PVY have been recognized: PVYO, or the common strain, which is severe in potato, but produces a mild mosaic in tobacco; and 2) PVYN ('necrotic' strain), which is mild in potato but is severely and systemically necrotic in tobacco, and from which the 'necrotic' name is derived. About S. brevicaule, S. berthaultii and S. capsicibaccatum Simko et al. (2007), indicate that these species are genetic resistance sources for other plant pathogens, for example, S. brevicaule for Globodera pallida, S. berthaultii and $S$ capsicibaccatum for Phytophthora infestans.

The principal modes of PVY transmission are the vegetative propagation of infected material, aphid transmission and, to a lesser extent, contact (Quenouille et al., 2013; Lacomme et al., 2017). By another hand Kreuz et al. (2020), points out that the differences in PVY and PLRV incidences between potato crops growing at different altitudes likely reflects the greater abundance of their aphid vectors below $3000 \mathrm{~m}$. In a recent study on native potatoes viruses in the P'alta loma community $(3750 \mathrm{~m})$, Colomi, Cochabamba, the presence of different species of aphids is reported, including Myzus persicae (Salazar, 2020). A probable explanation in these high Andean areas is that the aphids increase could be the increase of the other diversification crops, the intensification of cultivation of modern varieties or climatic variations effects. The PVY and PLRV viruses could have an impact on long time in situ conservation and agriculture in general. According to Quenouille et al. (2013), the Potato Virus Y (PVY) was first associated with a disease-causing potato degeneration in the early 1930s and, Kreuze et al. (2020), points out that Potato Virus Y (PVY) and Potato Leaf Roll Virus (PLRV) are now the most damaging viruses of potato worldwide, with PVY having overtaken PLRV as the most important.

\section{Conclusions}

In conclusion, in the high Andean zones and inter-Andean valleys of the study area, some species of wild potatoes, are infected with PVX, PVY and PLRV viruses and not with APLV and APMoV. In the high Andean areas with intensive potato cultivation, $S$. acaule, is infected with PVX and S. megistacrolobum with PVY and PLRV; however, in the inter-Andean valley areas with intensive potato cultivation, $S$. brevicaule is infected with PVY and S. berthaultii with PVY and PLRV. In isolated or remote areas S. capsicibaccatum (Liriuni), $S$. microdontum (Incallajta), S. brevicaule (Tupiza) and Solanum spp. (Pacuni) they are not contaminated with any analyzed viruses.

\section{Authors' Contributions}

MCM: Study elaboration, samples collection in the field, processing laboratory, data analysis and interpretation, drafting of the manuscript, revision original draft. NTP: Project revision, supervision, data analysis and interpretation, revision of the manuscript, review and editing. Both authors read and approved the final manuscript.

\section{Acknowledgements}

This research was funded by ASDI-UMSS via project PIA.ACC.01, which allows for research into the effects of climate change on Andean tuber crops. Thanks, are also owed to Martin Fernández of the P'alta Loma community, Colomi, Cochabamba, Francisco Choque and Rogelio Calle (Humanata community, Province of Camacho, La Paz), all of whom helped in field work. Henry López Salinas assisted in different parts of this work, and thanks are also Yuri Antezana and Saúl Ovando, of INAF-Cochabamba technicians, whom helped 
in samples collection of Aguascalientes communities. Finally, thanks are due to the Labimed Laboratory, Faculty of Medicine - UMSS for assistance in reading virus plates.

\section{Conflict of Interests}

The authors declare that there are no conflicts of interest related to this article.

\section{References}

Bertschinger L, Scheidegger UC, Luther K, Pinillos O, Hidalgo A (1990). La incidencia de virus de papa en cultivares nativos y mejorados en la sierra peruana. Revista Latinoamericana de la Papa 3:62-79.

Barker H, Finlay M, Dale B (2006). Resistance to viruses in potato. In: Loebenstein G, Carr JP (Eds). Natural Resistance Mechanisms of Plants to Viruses. Springer. Netherlands pp 341-366.

Cai X K, Spooner DM, Jansky SH (2011). A test of taxonomic and biogeographic predictivity: Resistance to Potato virus Y in wild relatives of the cultivated potato. Phytopathology 101:1074-1080.

Coca Salazar Evelyn L (2018). Incidencia de virus en papas nativas en comunidades del municipio de Colomi, Cochabamba. Facultad de Ciencias y Tecnología, Carrera de Biología. Universidad Mayor de San Simón. Tesis Licenciatura en Biología. Cochabamba, Bolivia.

Coca Morante M (2019). Impact of pests and diseases of Andean tubers in a context of climate change on domestication centers of Bolivia. Impreso en Talleres Gráficos "Kipus”. Cochabamba, Bolivia, pp 100.

Dempewolf H, Anderson Baute GJ, Kilian B, Smith Ch, Guarino L (2017). Past and future use of wild relatives in crop breeding. Crop Science 57:1070-1082. https://doi.org/10.2135/cropsci2016.10.0885

Fribourg CE (1980) Historia y distribución de los virus de la papa en América Latina. Fitopatología 15 (2):13-24.

Garcia W, Gandarillas A (1992). Incidencia virotica en campos de tuberculo-semilla de papa en certificacion y campos comerciales. Revista de Agricultura 21:29-33.

Hawkes JG, Hjerting JP (1989). The potatoes of bolivia: their breeding value and evolutionary relationships. Clarendon Press, Oxford.

Ford-Lloyd BV, Schmidt M, Susan J. Armstrong, Barazani Oz, Engels Jan, Hadas Rivka, ... Maxted N (2011). Crop wild relatives-undervalued, underutilized and under threat? BioScience 61(7):559-565. https://doi.org/10.1525/bio.2011.61.7.10

Kreuze JF, Souza-Dias JAC, Jeevalatha A, Figueira AR, Valkonen JPT, Jones RAC (2020). Viral diseases in potato crop. In: Campos H, Ortiz O (Eds). The Potato Crop, Its Agricultural, Nutritional and Social Contribution to Humankind. Chapter 11, pp 389-429. Springer Nature Switzerland AG. https://doi.org/10.1007/978-3-03028683-5_11

Lacomme C, Glais L, Bellstedt DU, Dupuis B, Karasev AV, Jacquot E E (2017). General characteristics of potato virus Y (PVY) and its impact on potato production - an overview. In: Lacomme C, Jacquot (Eds). Potato virus Y: biodiversity, pathogenicity, epidemiology and management pp 1-19. https://doi.org/10.1007/978-3-31958860-5_1

Ochoa CM (1990). The potatoes of South America: Bolivia. Cambridge University Press. Cambridge.

Quenouille J, Vassilakos N, Moury B (2013). Potato virus Y: a major crop pathogen that has provided major insights into the evolution of viral pathogenicity. Molecular Plant Pathology 14(5):439-452. https://doi.org/10.1111/mpp.12024

Simko I, Shelley Jansky, Sarah Stephenson, Spooner D (2007). Genetics of resistance to pests and disease. In: Vreugdenhil D (Ed). Potato Biology and Biotechnology Advances and Perspectives. Wageningen University and Research Centre Wageningen, The Netherlands. 
Coca Morante M and Tapia Ponce N (2021). Not Sci Biol 13(3):10986

OPEN ACCESS

(c) (i)

The journal offers free, immediate, and unrestricted access to peer-reviewed research and scholarly work. Users are allowed to read, download, copy, distribute, print, search, or link to the full texts of the articles, or use them for any other lawful purpose, without asking prior permission from the publisher or the author.

License - Articles published in Notulae Scientia Biologicae are Open-Access, distributed under the terms and conditions of the Creative Commons Attribution (CC BY 4.0) License.

(C) Articles by the authors; SHST, Cluj-Napoca, Romania. The journal allows the author(s) to hold the copyright/to retain publishing rights without restriction. 